\title{
Book Reviews and Notices
}

A Dictionary of Iowa Place-Names, by Tom Savage. Iowa City: University of Iowa Press, 2007. xxiv, 349 pp. Notes, sources, index. \$19.95 paper.

Reviewer Sarah S. Uthoff is a reference librarian at Kirkwood Community College.

In his Dictionary of Iowa Place-Names, Tom Savage shows how much of Iowa's history is revealed on a map. There are waves of town incorporation. A single man, railroader John Blair, left his mark by naming a large number of towns. Early mail delivery was problematic because many towns changed names to be distinct. Some Iowans didn't want a town named after them and suggested friends, hometowns, or even first names of children as alternatives. Others openly sought the honor. The impact of the war with Mexico is evident in the number of names from people and events in that war.

The book's format follows that of the earlier From Ackley to Zwingle, by Harold Dilts et al. (1975), but Savage greatly expands on that previous work. Dilts cited 127 sources; Savage cites 598. Many libraries were consulted, but the work cries out for more primary research. It's more of a starting place than a definitive reference. The main section of both works is a listing of towns in alphabetical order with information about each name. Entries may discuss previous names for a town and why it changed and any interesting stories or legends associated with the name. However, what is included is uneven, and several interesting stories that I'm aware of are not included. When several possible stories exist, Savage seldom attempts to judge between them. Unlike Dilts's previous work, Savage's includes county names, what happened to former counties, lists of former towns, and changed names. This book belongs in every Iowa history collection.

Native American Placenames of the United States, by William Bright. Norman: University of Oklahoma Press, 2007. xviii, 600 pp. References. \$29.95 paper.

Reviewer W. Raymond Wood is professor emeritus of anthropology at the University of Missouri-Columbia. His most recent book is Prologue to Lewis and Clark: The Mackay and Evans Expedition (2003).

If you are curious about the origin of that odd-sounding name for a local town or landmark, this is the place to start, particularly since 